JPPUMA: Jurnal Ilmu Pemerintahan dan Sosial Politik UMA (Journal of Governance and Political Social UMA),

6 (2) (2018): 166-176, DOI: 10.31289/jppuma.v6i2.1996

JPPUMA: Jurnal Ilmu Pemerintahan dan Sosial Politik UMA

(Journal of Governance and Political Social UMA)

Available online http://ojs.uma.ac.id/index.php/jppuma

\title{
Hashtag \#2019GantiPresiden: \\ Sentimen Anti-petahana dan Orientasi Politik \\ Pemilih Pemula menghadapi Pilpres 2019 di Pematangsiantar
}

\section{Hashtag\#2019ChangePresident: \\ Anti-incumbent Sentiment and Political Orientation of the New Voters facing the 2019 Presidential Election in Pematangsiantar}

\author{
Erond Litno Damanik* \\ Program Studi Pendidikan Antropologi, Fakultas Ilmu Sosial \\ Universitas Negeri Medan, Indonesia
}

Diterima September 2018; Disetujui Desember 2018; Dipublikasikan Desember 2018

\begin{abstract}
Abstrak
Tujuan penelitian adalah memahami munculnya hashtag\#2019GantiPresiden dan orientasi politik pemilih pemula menghadapi Pemilihan Presiden 2019. Hashtag\#2019GantiPresiden disebarkan melalui media sosial, kaos, stiker, maupun deklarasi hashtag\#2019GantiPresiden di berbagai daerah. Hashtag\#2019GantiPresiden merupakan penggiringan opini, sentimen Anti-petahana dan dekontruksi succses story Presiden Petahana pada Pemilihan Presiden 2019. Gerakan ini menyasar Pemilih Pemula dan usia produktif yang tinggal di perkotaan. Adapun masalah utama dalam penelitian ini adalah benarkah hashtag\#2019GantiPresiden berdampak pada orientasi politik pemilih pemula menghadapi Pemilihan Presiden 2019?. Teori yang digunakan adalah Strategic speaker dari Lee dan Pinker. Pengumpulan data dilakukan melalui tehnik wawancara mendalam dan distribusi kuisioner Skala Likert kepada 100 informan penelitian. Hasil penelitian menunjukkan bahwa hashtag\#2019GantiPresiden berdampak pada 17 persen informan penelitian. Kontribusi penelitian ini menegaskan bahwa hashtag\#2019GantiPresiden berdampak sebagai alat penggiringan opini untuk memperkuat sentimen Antipetahana dan dekonstruksi succses story presiden petahana.

Kata kunci: hashtag\#2019GantiPresiden, Orientasi Politik, Pemilih Pemula.
\end{abstract}

\section{Abstract}

The aim of the research is to understand the emergence of hashtag\#2019ChangePresident and the political orientation of the new voters face the 2019 Presidential Election. Hashtag\#2019 ChangePresident through social media, $t$-shirts, stickers, as well as declaration of the hashtag\#2019ChangePresident in various regions in Indonesia. Hashtag\#2019ChangePresident is a coercion of opinion, Anti-incumbent sentiments and deconstruction of President Incumbent's success stories in the 2019 Presidential Election. This movement targets Beginner Voters and productive age who live in urban areas. The main problem in this research is the hashtag\#2019ChangePresident has an impact on the political orientation of the new voters facing the 2019 Presidential Election? The theory used is the strategic speaker from Lee and Pinker. Data collection was conducted through in-depth interview techniques and Likert Scale questionnaire distribution to 100 research informants. The results showed that the hashtag\#2019ChangePresident impacted 17 percent of research informants. The contribution of this study confirms that the hashtag\#2019ChangePresident has an impact as a means of driving opinions to strengthen the Anti-incumbent sentiment and deconstruction of the incumbent president's success stories.

Keywords: Hashtag\#2019ChangePresident, Political Orientation, Beginner Voters.

How to Cite: Damanik, E.L (2018). Hashtag \#2019GantiPresiden: Sentimen Anti-petahana dan Orientasi Politik Pemilih Pemula menghadapi Pilpres 2019 di Pematangsiantar. JPPUMA: Jurnal Ilmu Pemerintahan dan Sosial Politik UMA (Journal of Governance and Political Social UMA), 6 (2): 166-176.

*Corresponding author:

E-mail: eronddamanik@yahoo.com
ISSN 2549-1660 (Print)

ISSN 2550-1305 (Online) 


\section{PENDAHULUAN}

Hashtag \#2019GantiPresiden adalah simbol atau sandi yaitu teks yang berelasi terhadap pembentukan sikap koperatif dan antagonis terhadap pergantian presiden tahun 2019. Menurut (Page, 2012) hashtag adalah adaptasi modern dari intertekstualitas yang berfungsi sebagai tanda baca ekspresi. Hashtag\#2019GantiPresiden adalah indirect speech atau kalimat tidak langsung pada arena politik. Menurut (Pinker, 2011) ataupun (Pinker, Nowak, \& Lee 2008), indirect speech bukan hanya sebagai isyarat sosial politik tetapi juga sebagai sesuatu yang secara monoton diproduksi untuk mempengaruhi interpretasi dan keputusan audiens.

Hashtag\#2019Ganti Presiden adalah bentuk eksperimen terhadap masyarakat yang sengaja diciptakan pembicara kepada audiens untuk mendapatkan penerimaan atau penolakan dari masyarakat terhadap upaya pergantian presiden pada Pilpres 2019.

Hashtag\#2019GantiPresiden muncul sejak 11 April 2018 di Indonesia. Kemunculan hashtag dimaksudkan sebagai penggiringan opini, sentimen antipetahana dan dekonstruksi succses story terhadap incumbent presiden. Menurut (Weber, Garimella, \& Teka 2013), kecenderungan penggunaan hashtag pada arena politik (political hashtag tends) ialah untuk mengukur polarisasi dalam masyarakat. Pada arena politik, hashtag bekerja dengan dua cara yakni: (i) seed users yakni untuk mengetahui kecenderungan politik, dan (ii) assigned a fractional leaning yakni penandaan kecenderungan faksi-faksi dalam masyarakat. Menurut (Jaffares, 2014) politik hashtag adalah pergeseran ke arah penentuan sasaran secara hati-hati dari ide dan kebijakan atau inisiatif khusus yang dilakukan secara instrumental dan konsisten. Karena itu, hashtag berfungsi untuk mendapatkan hasil sesuai konteks yang disebarkan kepada masyarakat. Dengan
hashtag\#2019GantiPresiden dimaksudkan untuk mendapatkan dukungan ataupun penolakan masyarakat terhadap ide dan kebijakan pergantian presiden tahun 2019. Hashtag\#2019GantiPresiden

merupakan indirect speech yang disampaikan Pembicara Strategis (Strategic speaker) kepada audiens untuk mendapatkan sikap koperatif atau antagonis terhadap gerakan. Menurut (Lee \& Pinker 2010), teori Strategic Speaker adalah pidato tidak langsung yang disampaikan kepada audiens dengan alasan startegis yang tidak melibatkan kerjasama murni antara pembicara dan audiens tetapi kombinasi dari keduanya. Inti pokok teori Strategic Speaker adalah bahwa proposisi tidak langsung dapat memungkinkan penyangkalan yang masuk akal. Seseorang pendengar yang baik cenderung dapat menerimanya sementara seseorang pendengar tidak koperatif tidak dapat bereaksi secara antagonistik terhadap pembicara. Dengan demikian, hashtag\#2019GantiPresiden adalah eksperimen menemukan pendengar yang koperatif dan antagonis sebagai prediksi kritis terhadap hipotesis yang terletak di kepala pembicara.

Hashtag\#2019GantiPresiden ramai dibicarakan melalui cetak dan televisi dan terutama media sosial. Frekuensi produksi wacana pergantian presiden yang massif melalui berbagai cara (televisi, cetak dan media sosial) dilakukan untuk membentuk memori kolektif (collective memory) pada masyarakat. Strategi ini dilakukan terutama menyasar pemilih pemula dan usia produktif di perkotaan yang diharapkan menebarkannya hingga masyarakat di level grassroots di pedesaan. Karena itu, tujuan sebenarnya gerakan hashtag\#2019GantiPresiden adalah membentuk sikap politik masyarakat terhadap keharusan mengganti presiden di tahun 2019. Melalui gerakan ini, diharapkan orientasi masyarakat berpaling dari petahana Joko Widodo dan 
kukuh kepada tokoh lainnya yakni Prabowo Subianto.

Agenda politik yang diusung lewat gerakan hashtag\#2019GantiPresiden ialah: (i) menggiring dan meneguhkan opini publik terhadap keharusan pergantian presiden tahun 2019, (ii) memperkuat sentimen Anti-Petahana yakni Joko Widodo pada pemilihan presiden tahun 2019, dan (iii) mendekonstruksi success story kepemimpinan nasional Joko WidodoJusuf Kalla periode 2014-2019. Melalui pengarusutamaan pada ketiga wacana itu, diharapkan masyarakat pemilih untuk tidak ragu berpaling dari petahana kepada calon lain yakni Prabowo Subianto. Untuk menegaskan keharusan hashtag\#2019GantiPresiden maka tokohtokoh yang berada di balik wacana politik ini melakukan gerakan-gerakan antara lain: (i) memproduksi wacana hashtag\#2019GantiPresiden secara intensif melalui media cetak, televisi dan media sosial, (ii) melakukan deklarasi berbungkus demostrasi hashtag\#2019GantiPresiden di berbagai daerah di Indonesia, (iii) mendekonstruksi succses story petahana dengan cara tidak menyebarkannya melalui pemberitaan dan informasi melalui media cetak, televisi dan media sosial, dan (iv) menonjolkan tokohtokoh akademisi, politisi, praktisi hukum, ekonom dan lain-lain berupa kutipan singkat (quote) yang menggambarkan 'kegagalan' petahana presiden yang disebarkan melalui media cetak, televisi dan terutama media sosial.

Gerakan hashtag\#2019GantiPresiden hanya terfokus pada masyarakat urban (perkotaan), sedangkan bagi masyarakat grass roots seperti di pedesaan, hashtag dimaksud tidak signifikan. Namun, produksi

hashtag\#2019GantiPresiden wacana masyarakat perkotaan lambat laun diharapkan menular (contagion) pada level grass root dan masyarakat pedesaan. Pada masyarakat perkotaan, sasaran utama
hashtag\#2019GantiPresiden adalah pemilih pemula (begin voters) dan usia produktif. Pemilihan kelompok masyarakat ini didasarkan pada pertimbangan: pertama, pemilih pemula adalah kelompok yang karena usianya memiliki hak politik di pemilihan presiden. Karakter utama dari kelompok ini adalah bagian masyarakat yang baru mentas yang masih labil dalam menentukan sikap politiknya. Karena itu, kelompok ini merupakan bagian masyarakat yang paling mudah di pengaruhi, dan kedua bahwa usia produktif perkotaan adalah kelompok usia masyarakat yang paling aktif mengamati perubahan sosial, kultural, ekonomi dan politik. Di samping karena selalui memperhatikan kepentingan ekonomi dan politik terhadap diri pribadinya, sekaligus kelompok ini merupakan wakil masyarakat yang paling membutuhkan perubahan. Disatu sisi, mereka ini adalah kelompok masyarakat yang paling berkepentingan terhadap perubahan ekonomi dan politik (antistatus quo), tetapi sebagian kecil diantaranya berisikan individu-individu yang menginginkan atau pro-status quo.

Harus diakui bahwa, kemunculan hashtag ini berdampak pada orientasi politik di masyarakat. Sejak kemunculan hashtag pada bulan April 2018, polarisasi kelompok yang memandang sinis petahana presiden meningkat di masyarakat. Opini yang dibentuk ialah sentimen Antipetahana ataupun dekonstruksi succses story kepemimpinan Joko Widodo-Jusuf Kalla (2014-2019). Fenomena hashtag\#2019GantiPresiden semakin ramai dibicarakan ditingkat elitis terutama kelompok yang pro status quo, pemilih pemula dan usia produktif di perkotaan.

Pemilih pemula adalah masyarakat baru mentas di kancah politik dan berusia antara 17-21 tahun. Mereka ini adalah anggota masyarakat dengan usia yang masih relatif muda yang bercirikan 'labil politik' karena tiga hal: (i) orientasi politiknya cenderung bersumber dari 
patron politik lingkungan internal yakni orangtua, kerabat, dan teman sebaya, (ii) penentuan sikap politik pada figur-figur politik tertentu seringkali dilakukan tanpa melihat jejak rekam (track record) dan kinerja, dan (iii) secara phsikologis, usia muda merupakan kelompok masyarakat yang paling mudah dipengaruhi. Kelompok ini dapat menjadi pemilih rasional dan objektif apabila referensi orientasi politiknya cenderung rasional dan objektif. Namun, mereka juga bisa menjadi pemilih yang irasional dan nir-objektif apabila referensi orientasi politiknya cenderung menularkan irasionalitas dan nir-objektif. Kelompok ini rentan menjadi "korban politik' akibat patron politik seperti orangtua, kerabat, teman sebaya maupun partai politik ataupun tokoh yang berpengaruh dalam dirinya yang ada di sekitarnya. Karena itu, munculnya hashtag\#2019GantiPresiden dipastikan berdampak pada pembentukan orientasi dan sikap politik pemilih pemula menghadapi Pilpres 2019.

Penelitian ini dimaksudkan untuk melihat relasi antara hashtag\#2019GantiPresiden terhadap orientasi pemilih pemula terhadap Pemilihan Presiden (Pilpres) tahun 2019 di Pematangsiantar. Disadari bahwa, pentingnya orientasi politik ini menjadi peneguh (penetap) bagi sikap politik yakni tindakan politik (political action) terhadap pilihan politik (political choice) tahun 2019. Pematangsiantar adalah kota menengah (middle town) dan merupakan kota terbesar kedua setelah kota Medan di Sumatra Utara. Dilihat dari struktur masyarakatnya, maka kota ini adalah majemuk dan multikultur sehingga menarik untuk dikaji. Selain itu, kota ini dikenal dengan 'kota pelajar' sebab terdapat banyak sekolah dan perguruan tinggi dimana pelajar dan mahasiswa menempuh studinya. Dapat dipastikan bahwa hashtag\#2019GantiPresiden menyasar pelajar dan mahasiswa yakni pemilih pemula di kota ini. Karena itu, tujuan penelitian ini adalah untuk mendiskusikan dan memahami dampak hashtag\#2019GantiPresiden terhadap orientasi politik pemilih pemula menghadapi Pemilihan Presiden 2019 yang akan datang di Pematangsiantar.

\section{METODE PENELITIAN}

Penelitian ini dilakukan secara kualitatif dengan pendekatan hermeneutika. Pemilihan metode kualitatif cenderung karena penekanan pada proses dan makna dari objek yang dikaji, yakni semacam realitas yang terbangun secara sosial, subjektivitas yang diteliti dengan situasi yang terbentuk pada penelitian. Menurut (Denzin \& Lincoln 2011) penelitian kualitatif berupa mencari jawab atas permasalahan, pengalaman sosial dan makna dari suatu tindakan. Pendekatan teori Strategic speaker dari (Lee \& Pinker 2010) digunakan sebagai alat analisis yang diarahkan untuk meneliti orientasi politik pemilih pemula. Dalam hal penelitian ini, hashtag \#2019GantiPresiden adalah proposisi tidak langsung dari pembicara yang tidak memungkinkan penyangkalan masuk akal dari audiens. Dengan kata lain, hashtag\#2019GantiPresiden adalah eksperimen menemukan pendengar yang koperatif dan antagonis sebagai prediksi kritis terhadap hipotesis yakni kemungkinan pergantian presiden dari petahana tahun 2019 .

Pada penelitian ini, informan ditetapkan terdiri dari 100 orang pemilih pemula yang bermukim dan sekolah di Pematangsiantar. Informan di pilih 10 orang dari 10 SMA kelas II atau kelas III atau kuliah di Pematangsiantar. Keseluruhan pemilih pemula dalam penelitian ini adalah berusia 17-21 yakni orang-orang yang baru mentas di politik pada Pemilihan Presiden tahun 2019, memiliki smartphone dan mengikuti berita serta informasi hashtag\#2019GantiPresiden. Alat pengumpul data adalah kuisioner berisi 15 pertanyaan yang terdiri dari 4 opsi 
jawaban tersedia. Setiap informan diminta untuk memberi tanda contreng (V) pada opsi jawaban menurut informan. Jawaban ditabulasi berdasarkan Skala Likert untuk mendapatkan persentasi tentang ada dan tidaknya relasi hashtag \#2019GantiPresiden terhadap orientasi politik pemilih pemula pada Pilpres 2019 yang akan datang.

Muatan kuisioner terbagi dalam 3 komponen: (i) pengetahuan terhadap hashtag\#2019GantiPresiden, (ii) reaksi terhadap hashtag\#2019GantiPresiden dan (iii) sikap terhadap hashtag\#2019GantiPresiden. Komponen pertama adalah 5 pertanyaan mengenai hashtag baik dari media sosial, cetak ataupun televisi, komponen kedua berisi 5 pertanyaan tentang reaksi yakni pendapat, dan kegiatan terhadap hashtag seperti membaca, men-like, men-share atau mengomentari, dan komponen ketiga memuat 5 pertanyaan tentang sikap (orientasi) politik terhadap pemilihan presiden pada tahun 2019 yang akan datang.

Penelitian ini memfokuskan diri pada masalah penelitian yakni: benarkah hashtag\#2019GantiPresiden memiliki relasi terhadap pembentukan orientasi politik pemilih pemula menghadapi Pilpres
2019 di Pematangsiantar?. Penelitian ini dilakukan selama dua bulan yakni Juni-Juli 2017 di Pematangsiantar yang melibatkan 4 tenaga pendamping penelitian. Penjajagan sekolah dan calon informan dilakukan pada minggu pertama bulan Juni, kemudian distribusi kuisioner dilakukan pada minggu ke tiga bulan Juni. Pada minggu keempat Juni dan minggu pertama Juli dilakukan wawancara mendalam terhadap 10 informan yang dianggap memiliki jawaban tertinggi berdasarkan Skala Likert. Setelah kegiatan ini, maka pada minggu ke 2 dan 4 bulan Juli dilakukan analisis dan penulisan naskah.

\section{HASIL DAN PEMBAHASAN}

Sebagaimana dikemukakan di atas, informan penelitian ini terdiri dari 100 orang pemilih pemula yang sekolah di Pematangsiantar. Mereka adalah pemilih pemula yakni pelajar kelas XI dan XII yang diperoleh dari 10 sekolah, memiliki smartphone dan aktif mengikuti perkembangan berita dan informasi hashtag\#2019GantiPresiden. Adapun profil informan ini adalah sebagaimana diperlihatkan pada tabel 1 di bawah ini, yaitu:

Tabel 1. Profil informan penelitian

\begin{tabular}{|c|c|c|c|c|c|c|c|c|c|}
\hline \multirow[t]{2}{*}{ Sekolah } & \multirow{2}{*}{$\begin{array}{l}\text { Jumlah } \\
\text { (orang) }\end{array}$} & \multicolumn{2}{|c|}{ Jenis Kelamin } & \multicolumn{2}{|c|}{ Kelas } & \multicolumn{4}{|c|}{ Agama } \\
\hline & & L & $\mathbf{P}$ & XI & XII & I & $\mathbf{K P}$ & Kh & B \\
\hline SMAN A & 10 & 5 & 5 & 5 & 5 & 2 & 7 & 1 & - \\
\hline SMAN B & 10 & 4 & 6 & 6 & 4 & 3 & 5 & 2 & - \\
\hline SMAN C & 10 & 7 & 3 & 6 & 4 & 3 & 4 & 3 & - \\
\hline SMAN D & 10 & 6 & 4 & 7 & 3 & 4 & 5 & 1 & - \\
\hline SMAS $_{1}$ & 10 & 5 & 5 & 5 & 5 & 1 & 4 & 2 & 3 \\
\hline SMAS 2 & 10 & 7 & 3 & 6 & 4 & 3 & 3 & 3 & 1 \\
\hline SMAS $_{3}$ & 10 & 3 & 7 & 3 & 7 & 1 & 3 & 3 & 3 \\
\hline SMKS 1 & 10 & 6 & 4 & 3 & 7 & 2 & 4 & 4 & - \\
\hline SMKS 2 & 10 & 5 & 5 & 3 & 7 & 1 & 5 & 4 & - \\
\hline $\mathrm{SMKS}_{3}$ & 10 & 4 & 6 & 5 & 5 & 1 & 6 & 3 & - \\
\hline $\mathbf{N}$ & 100 & 52 & 48 & 49 & 51 & 21 & 46 & 26 & 7 \\
\hline
\end{tabular}

Tabel 1 di atas memperlihatkan bahwa dari 100 informan berasal dari sekolah menengah atas (SMA) di Pematangsiantar. Apabila dilihat dari pengelola sekolah, maka 4 sekolah merupakan sekolah negeri dan 6 diantaranya adalah sekolah swasta. Dari 6 sekolah swasta, tiga diantaranya adalah 
SMA dan tiga lagi adalah SMK. Bila dilihat dari jenis kelaminnya, maka 52 orang atau 52 persen adalah laki-laki sedangkan 48 orang atau 48 persen adalah perempuan. Dilihat dari kelasnya, maka informan terdiri dari 49 orang atau 49 persen adalah pelajar kelas XI dan sisanya yakni 51 orang atau 51 persen adalah pelajar kelas XII. Bila dilihat dari aspek keyakinan pelajar, maka 21 persen informan beragama Islam, 46 persen beragama Protetstan, 26 persen beragama Katolik, dan 7 persen beragama Buddha. Data ini memperlihatkan bahwa pemilih pemula mewakili setiap jenjang sekolah atas yakni SMA dan SMK yang terletak di Pematangsiantar.

Berdasarkan kuisioner yang didistribusikan kepada keseluruhan informan diperoleh informasi bahwa 76 persen informan mengakui mengetahui tentang adanya hashtag\#2019GantiPresiden melalui media sosial yakni Facebook yang mereka miliki. Informan mengakui bahwa hashtag\#2019GantiPresiden lebih sering diikuti dari media sosial daripada media televisi dan cetak. Kenyataan ini menunjukkan bahwa pemilih pemula dewasa ini telah melek teknologi. Setiap pemilih pemula pada penelitian ini memiliki android atau smarthphone yang didalamnya tersedia aplikasi media sosial seperti Facebook, WhatsApp, Twitter, Youtube bahkan Instagram. Jenis aplikasi lainnya adalah aplikasi game online ataupun aplikasi $e$-Commerce dari berbagai produk. Namun, tidak satupun informan mengakui bahwa di dalam smartphone yang mereka miliki terdapat aplikasi media daring tertentu. Kenyataan ini menunjukkan bahwa pemilih pemula telah akrab dengan teknologi, tetapi penggunaannya masih sebatas sarana komunikasi, swafoto ataupun sekedar perangkat bersosialisasi. Tampak bahwa, penggunaan smartphone belum maksimal untuk keperluan dan pendukungan pendidikan yang mereka lakukan. Aplikasi mesin pencari (Google) misalnya, masih dipergunakan untuk mengakses beritaberita daring ataupun bahan belajar dari blogger. Tidak satupun informan menggunakan smartphone yang dimiliki untuk mengakses $e$-Book atau mengakses Youtube yang memberikan layanan pendidikan.

Hashtag\#2019GantiPresiden bagi pemilih pemula di Pematangsiantar cenderung diperoleh dari pembacaan di media sosial daripada media cetak ataupun televisi. Media sosial utama informasi hashtag\#2019GantiPresiden adalah Facebook, WhatsApp dan Twitter. Berikut ini adalah penjelasan penggunaan media pada pemilih pemula di Pematangsiantar.

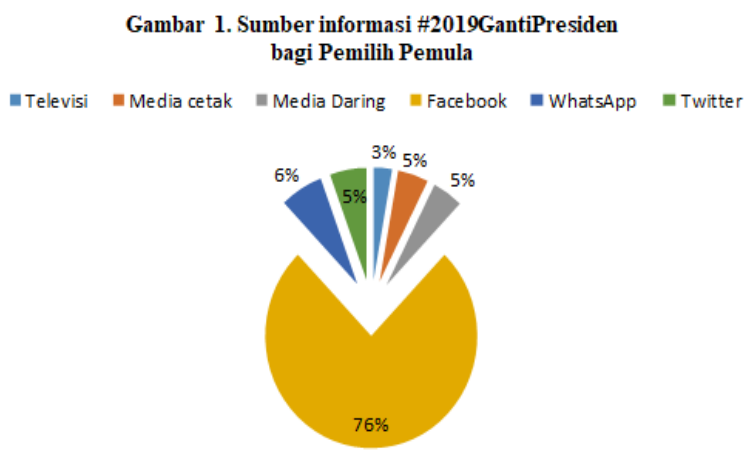

Gambar 1 di atas memperlihatkan bahwa 76 persen informasi tentang hashtag\#2019GantiPresiden pada mulanya diperoleh dari media sosial Facebook, 6 persen melalui WhatsApp, masing-masing 5 persen dari media cetak, daring dan Twitter, serta 3 persen berasal dari pemberitaan televisi. Data ini menunjukkan bahwa preferensi politik pemilih pemula cenderung berasal dari media sosial daripada media cetak dan televisi. Karena itu, apabila informasi yang mereka terima dari media sosial tidak menunjukkan keseimbangan dan objektifitas, maka orientasi politik pemula dapat dipengaruhi hashtag ini. Kemudian, informasi tentang viral hashtag\#2019GantiPresiden menjadi perbincangan di kelompok mereka sendiri (teman satu sekolah) tanpa berupaya mencaritahu asal usul dan tujuan pembuatan hashtag dimaksud. Demikian 
pula mereka jarang sekali menanyakan maksud dan tujuan hashtag\#2019GantiPresiden kepada patron politik seperti orangtua, kerabatnya ataupun gurunya.

Pemilihan Media Sosial sebagai penyampai pesan hashtag\#2019Ganti Presiden disebabkan kontribusi teknologi digital yang berkembang pesat dewasa ini. Masyarakat perkotaan yang menjadi sasaran gerakan ini dinilai sebagai kelompok masyarakat yang dekat dengan smartphone yang selalu memonitor perubahan dan perkembangan sosial lewat kontribusi Web Technology 4.0. Sebagaimana disebut (Ardha, 2014), media sosial telah memainkan dan akan terus memainkan peran penting dalam kampanye politik politik. Selain itu, (Budiyono, 2015) menyebut bahwa media sosial cukup potensial sebagai sarana komunikasi politik. Namun, keprihatinan muncul manakala bahasa yang semestinya menjadi alat komunikasi yang baik, justru dimanfaatkan untuk menyerang, mengejek, merendahkan orang lain dan perilaku destruktif lainnya.

Informan mengaku bahwa hashtag tersebut masuk ke akun Facebook melalui kiriman teman ataupun dampak penandaan (tag) oleh teman-temannya di Facebook. Bentuk informasi yang diterima adalah: (i) gambar tokoh dan quote yang menyuarakan

hashtag\#2019GantiPresiden, (ii) simbol hashtag\#2019GantiPresiden, pemberitaan deklarasi 2019GantiPresiden diberbagai daerah, dan (iv) video atau meme tentang gerakan hashtag\#2019GantiPresiden. Melalui WhatsApp, beberapa informan mengaku pernah mendapatkan kiriman video ataupun meme politik tentang gerakan hashtag\#2019GantiPresiden. Berikut di bawah ini adalah penjelasan tentang bentuk-bentuk informasi viral hashtag\#2019GantiPresiden pada pemilih pemula di Pematangsiantar.
Gambar 2. B entukinformasi\#2019GantiPresiden melaluiFacebook

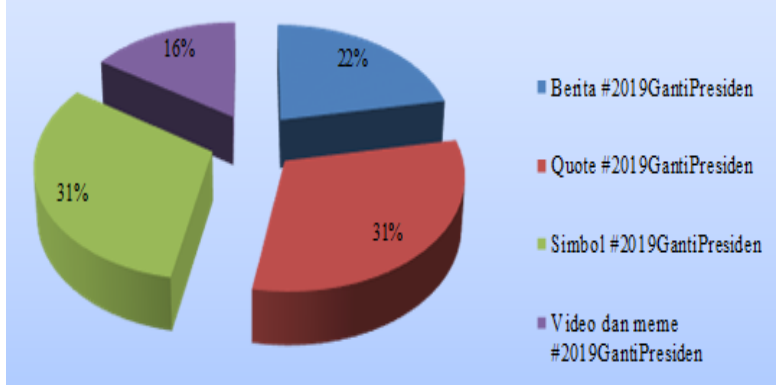

Data di atas memperlihatkan bahwa, bentuk-bentuk informasi tentang viral hashtag\#2019GantiPresiden yang diperoleh pemilih pemula di Pematangsiantar, 31 persen diantaranya adalah quote (pesan singkat) serta simbol hashtag\#2019GantiPresiden. Demikian pula sebesar 22 persen mengaku menerima kiriman berita tentang\#2019GantiPresiden dan 16 persen sisanya adalah kiriman meme dan video tentang hashtag\#2019GantiPresiden. Bila dilihat dari persentasi bentuk berita yang diterima informan, maka kecenderungan informasi hashtag yang diterima adalah dalam bentuk quote dan simbol hashtag\#2019GantiPresiden. Indikasi ini menunjukkan bahwa informan penelitian tidak pernah membaca berita-berita deklarasi yang berbungkus hashtag\#2019GantiPresiden di berbagai daerah. Kenyataan ini menjadi ironi bahwa pelajar tidak sampai pada nalar atau logika penyebab munculnya hashtag. Sekaligus, fenomena ini menunjukkan bahwa sikap kritis ataupun skeptis pelajar masih sangat kurang dalam menerima sebuah informasi atau berita. Selanjutnya, adapun persepsi pemilih pemula terhadap viral hashtag\#2019GantiPresiden

Pematangsiantar adalah seperti ditunjukkan pada gambar 3 di bawah ini, yaitu: 


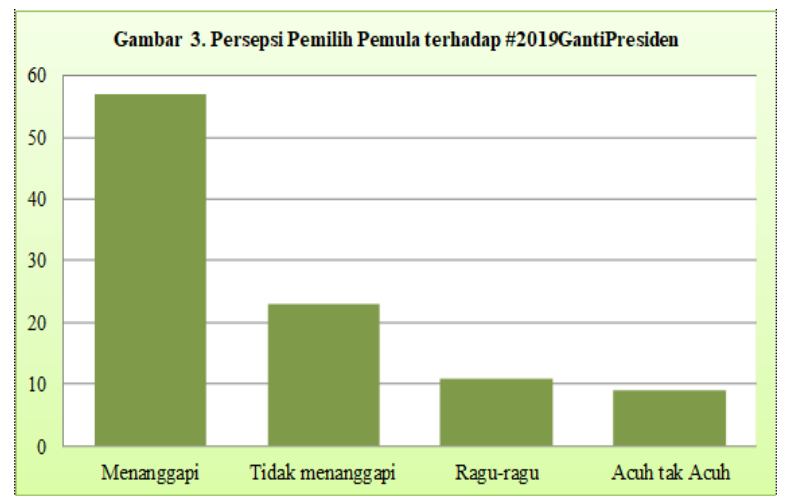

Data pada gambar $3 \mathrm{di}$ atas memperlihatkan bahwa 57 persen informan menyatakan mengabaikan hashtag\#2019GantiPresiden, 23 persen menyatakan mengikutinya, 11 persen menyatakan ragu-ragu dan 9 persen menyatakan tidak menanggapi hashtag dimaksud. Data ini memperlihatkan bahwa, terdapat setidaknya 23 informan yang terpengaruh terhadap berkembanya hashtag\#2019GantiPresiden. Namun, pada saat ditanyakan langsung kepada informan terkait pernyataan 'mengikuti', informan menjawab bahwa mereka mengikuti pemberitaan dan informasi hashtag dimaksud secara serius. Pernyataan ini tidak serta merta telah mengubah sikab dan orientasi politik mereka di tahun 2019, yakni apakah mendukung petahana presiden atau justru berpaling ke penantang petahana. Sebagai catatan bahwa pada saat penelitian ini dilakukan, calon penantang petahana Joko Widodo belum terungkap. Walaupun desas desus yang berkembang adalah Prabowo Subianto, tetapi tokoh ini belum belum menyatakan diri untuk maju dalam kontestasi presiden tahun 2019 sewaktu penelitian selesai dilakukan.

Respon pemilih pemula (informan) terhadap hasgtag\#2019GantiPresiden cukup beragam. Namun, calon presiden penantang petahana pada saat penelitian ini dilakukan belum muncul di permukaan. Namun, kemungkinan besar bahwa Prabowo Subianto adalah sosok penantang presiden petahan. Kemungkinan itu mereka dapat setelah mengikuti berita dan informasi yang beredar di media sosial, cetak

maupun

televisi.

Hashtag\#2019GantiPresiden terhadap pemilih pemula dalam menghadapi Pemilihan Presiden tahun 2019 adalah sebagai berikut: sebanyak 63 persen menyatakan

bahwa hashtag\#2019GantiPresiden tidak memengaruhi orientasi politik mereka dalam menentukan pilihan politik calon presiden tahun 2019. Dalam arti bahwa, informan ini tetap mendukung petahana Presiden yakni Joko Widodo sebagai calon Presiden Republik Indonesia periode 2019-2014. Selanjutnya, sebanyak 17 persen informan menyatakan bahwa hashtag\#2019GantiPresiden berdampak pada orientasi politik mereka dalam menentukan pilihan politik terhadap calon presiden tahun 2019. Dalam arti bahwa, hashtag tersebut kemungkinan mengubah pilihan politik mereka dalam mendukung Joko Widodo sebagai calon presiden Republik Indonesia periode 2019-2014. Walaupun demikian, mereka tidak menyebutkan sosok atau figur yang cocok menjadi pesaing Joko Widodo pada kontestasi Pilpres 2019. Selanjutnya, sebesar 8 persen menyatakan ragu-ragu terhadap hashtag dimaksud dan sisanya sebesar 12 persen menyatakan belum menentukan orientasi politiknya pada Pilpres 2019 yang akan datang.

Tampak bahwa, walaupun hashtag\#2019GantiPresiden belum memiliki sosok atau figur calon presiden sebagai penantang petahana, tetapi hashtag dimaksud mampu merubah orientasi politik pemilih pemula di Pematangsiantar. Demikian pula terdapat pemilih pemula yang apatis sebanyak 8 orang yang sama sekali mengabaikan atau tidak merespon hashtag dimaksud. Akan tetapi, terdapat pula sebanyak 12 persen yang masih menyebutkan orientasi pilihan politiknya pada Pilpres 2019 yang akan datang. Ini berarti, pemilih pemula merupakan kelompok masyarakat yang labil dalam politik. 
Pemilihan model deklarasi hashtag\#GantiPresiden berbungkus unjukrasa di dunia nyata adalah upaya peneguhan aksi di masyarakat. Menurut (Davis, 2013), kampanye politik secara tradisional yakni door-to-door ataupun pengeras suara di trotoar menghadapi ancaman serius yang terus berkembang dewasa ini. Karena itu, sejalan dengan perkembangan teknologi informasi dan komunikasi dewasa ini terdapat transisi kehidupan politik secara tradisional ke era digital. Mengikuti cara berfikir ini, gerakan hashtag\#2019GantiPresiden

di maksudkan untuk mengajak sejumlah massa, diliput media televisi dan media cetak sehingga intensitas pemberitaan terjadi massif di masyarakat. Selanjutnya, pencetakan dan penjualan stiker dan kaos bertuliskan hashtag\#2019GantiPresiden dimaksudkan bukan saja mengukur dukungan politik personal terhadap keinginan pergantian presiden, tetapi juga sebagai cara mendapatkan pundi-pundi politik.

Munculnya hashtag\#GantiPresiden adalah rentetan dari pidato Prabowo Subianto pada acara Wadah Global Gathering tanggal 22 Maret 2018 di Jakarta. Pada saat itu, Prabowo Subianto menyetir novel fiksi Ghost Fleet yang ditulis P. W. Singer dan August Cole yang menyebut Indonesia pada tahun 2030 'tidak ada lagi' atau bubar (Rahadian, 2018). Kemunculan hashtag\#2019GantiPresiden dapat dipandang dari tiga hal. Pertama, gerakan dimaksudkan untuk mengeliminasi succses story yakni menimbulkan keraguan terhadap kesuksesan pembangunan yang telah dilakukan Presiden Joko WidodoJusuf Kalla. Kedua, gerakan dimaksudkan untuk 'memaksa masyarakat' terhadap 'keharusan' pergantian presiden di tahun 2019, dan ketiga 2019 adalah tahun politik yakni periodeisasi kepemimpinan nasional melalui Pemilihan Umum Presiden pada bulan April. Namun, melihat upaya-upaya massif sejumlah tokoh-tokoh di front stage gerakan hashtag\#2019GantiPresiden tampak bahwa gerakan dimaksud ialah untuk mengganti presiden dari Joko Widodo ke yang lain yakni Prabowo Subianto.

Kemunculan tagar ini berawal dari ucapan Mardani Ali Sera, Ketua DPP Partai Keadilan Sejahtera (PKS) pada sebuah acara televisi swasta (Hantoro, 2018). Setelah acara itu, berkembang hashtag\#2019GantiPresiden di media sosial, pencetakan kaos dan stiker, ataupun sejumlah unjukrasa berwujud deklarasi hashtag\#2019GantiPresiden. Reaksi masyarakat di daerah cenderung beragam. Sebagian masyarakat menerima dan sebagaian daerah seperti di Batam, Kalimantan Barat, Pekan Baru, Jawa Barat, Jawa Timur, Gorontalo dan lain-lain menolak

hashtag\#2019GantiPresiden.

Kenyataan seperti ini menjadi jelas kelihatan bahwa keberadaan Partai Politik (Parpol) seperti Partai Keadilan Sejahtera (PKS), Gerakan Indonesia Raya (Gerindra), Partai Amanat Nasional (PAN) dan belakang menyusul Partai Demokrat berkoalisi sebagai penantang incumbent (Petahana) Joko Widodo. Karena itu, gerakan Hashtag\#2019GantiPresiden dimaksudkan untuk membangun sentimen 'asal bukan' atau anti-incumbent. Sekaligus menakar kekuatan dari kelompok masyarakat yang menginginkan pergantian presiden dari Joko Widodo ke Prabowo Subianto. Viral perbincangan dan deklarasi hashtag\#2019GantiPresiden tampak semakin ramai karena proses pemilihan umum 2019 semakin dekat. Apalagi setelah dua pasangan kandidat presiden dan wakil presiden yakni petahana Joko Widodo-Maaruf Amin dan Prabowo Subianto-Sandiaga Uno telah mendaftarkan diri ke Komisi Pemilihan Umum (KPU) pada 10 Agustus 2018. Karena itu, gerakan hashtag\#2019GantiPresiden diprediksi semakin intensif melalukan deklarasi di daerah-daerah seluruh Indonesia. 
Tampak bahwa, hashtag\#2019GantiPresiden

penggerak selalu memproduksi wacana berupa 'kegagalan Pemerintah' yakni dekonstruksi terhadap citra politik Joko Widodo pada setiap aspek, seperti: nilai tukar rupiah yang merosot terhadap Dollar Amerika, daya beli masyarakat yang rendah, pengangguran yang tinggi, kapitalisasi pendidikan, lapangan kerja yang kecil, hutang luar negeri yang meninggi, harga Tarif Dasar Listrik (TDL), Bahan Bakar Minyak (BBM) maupun Sembilan Bahan Pokok (Sembako) yang tinggi maupun persekongkolan pemerintah dengan pihak Asing (Amerika) dan Aseng (Tiongkok). Tokoh-tokoh di front stage gerakan ini adalah seperti Neno Warisman, Ratna Sarumpaet maupun Ahmad Dhani. Bila melihat pergerakan di Media Sosial seperti Facebook, Twitter, WhatsApp dan lain-lain, tokoh-tokoh front stage dan back stage gerakan hashtag\#2019Ganti Presiden jarang sekali men-like, men-share atau mengomentari 'succses story' Joko Widodo dan Jusuf Kalla berupa pembangunan infrastruktur seperti bandara, bendungan, LRT, jalan bebas hambatan, Kartu Indonesia Sehat (KIS), BPJS, jalan Trans Papua, Trans Kalimantan, Trans Sulawesi, Kereta Api, penanganan gempa bumi di Nusa Tenggara, bahkan sukses besar Indonesia di Asian Games 2018 yang berada di posisi 4 besar dari 45 negara yang berpartisipasi. Dengan demikian, hashtag\#2019GantiPresiden adalah produksi wacana sentimen anti-petahana menghadapi Pilpres 2019.

Apabila merujuk pada data-data yang disampaikan seluruh informan dalam penelitian ini ditemukan indikasi bahwa hashtag\#2019GantiPresiden tidak berdampak pada pengalihan orientasi politik pemilih pemula menghadapi Pilpres 2019. Dalam arti bahwa, pemilih pemula masih mengunggulkan presiden petahana sebagai calon presiden pada periode kedua. Namun, bila penantang presiden petahana sudah defenitif diumumkan, maka boleh jadi orientasi politik pemilih pemula dapat berpaling atau juga mendukung presiden petahana. Pembangunan infrastruktur maupun karakter merakyat menjadi faktor utama dukungan kepada presiden petahana. Walaupun demikian, bukan tidak mungkin orientasi politik pemilih pemula yang baru mentas di panggung politik berpaling dari Joko Widodo karena pengaruh orangtua, kerabat, teman sebaya, ataupun patronpatron politik yang ada di sekitar mereka. Oleh karena itu, kontra wacana berupa menonjolkan basis kinerja melalui media sosial perlu digiatkan sehingga dapat melawan hashtag\#2019GantiPresiden. Dengan begitu, konsumsi berita dan informasi pemilih pemula dapat berimbang antara hashtag\#2019GantiPresiden dengan keharusan mendukung presiden petahana melanjut ke periode kedua.

Pencetus hashtag\#2019GantiPresiden muncul dari strategic speaker yang memiliki alasan tertentu untuk menciptakan sentimen anti-petahana serta dekonstruksi succses story petahana. Pemilihan media sosial sebagai sarana mengukur kekuatan yaitu mendapatkan penerimaan atau penolakan dari masyarakat. Kenyataan seperti ini dapat wujud karena 'strategic speaker' tidak berkeinginan berhadapan langsung dari masyarakat tetapi menjadikan media sosial sebagai cara mendapatkan sikap kooperatif atau antagonis. Jadi, hashtag\#2019GantiPresiden dimaksudkan untuk menyampaikan pesan kepada audiens terkait rencana pergantian presiden di tahun 2019 yang akan datang.

\section{SIMPULAN}

Novelty penelitian ini menyatakan bahwNovelty penelitian ini menyatakan bahwa tidak terdapat dampak signifikan antara hashtag\#2019GantiPresiden terhadap orientasi politik pemilih pemula menghadapi Pilpres 2019. Hashtag\#2019GantiPresiden diproduksi 
strategic speaker yang tidak menginginkan penolakan langsung dari audiens. Hashtag ini dimaksudkan untuk membangkitkan sentimen anti-petahana sekaligus mendekonstruksi succses story dari presiden petahana. Sejak kemunculan hashtag pada bulan April 2018 yang diproduksi secara massif di media sosial, deklarasi di berbagai daerah maupun sosialisasi berupa stiker dan kaos, hingga penelitian ini dilakukan (Juni-Juli 2018), tetapi tujuannya untuk mengubah orientasi politik terutama pemilih pemula belum berhasil. Karena itu, strategi yang dicanangkan strategic speaker melalui hashtag\#2019GantiPresiden berupa sentimen anti-petahana maupun mendekonstruksi succses story kepada masyarakat cenderung tidak berhasil.

Alasan utama kegagalan hashtag ini adalah tidak munculnya tokoh utama di balik gerakan hashtag yakni sosok yang menantang petahana. Alasan lainnya ialah karena hashtag ini cenderung mengeliminasi 'kesuksesan' petahana yang sebenarnya telah terbaca bahkan dinikmati masyarakat. Karena itu, hashtag ini tidak berfungsi efektif terhadap orientasi politik pemilih pemula karena keberadaan hashtag justru dianggap sebagai cerminan kebencian kepada presiden petahana. Jadi, boleh saja hashtag diproduksi melalui media sosial yakni sebagai cara mendapatkan sikap koperatif maupun antagonis, tetapi isi hashtag tidak mengumbar sentimen ataupun dekonstruksi keberhasilan yang dicapai calon lain. Justru hashtag harus tetap menggambarkan realitas sosial yang melalui media sosial, cetak maupun televisi masyarakat dapat membacanya secara langsung.

\section{DAFTAR PUSTAKA}

Ardha, B. (2014). Sosial Media sebagai media kampanye Partai Politik 2014 di Indonesia. Jurnal Visi Komunikasi, 13(01), 105-120.

Budiyono. (2015). Fenomena Komunikasi Politik dalam Media Sosial. Iptek-Com, 17(2), 143160.

Davis, B. (2013). Hashtag Politics: the Polyponic Revolution \#Twitter. Pepperdine Journal of Communication Reseacrh, 1(4), 16-22. Retrieved from http://digitalcommons.pepperdine.edu

Denzin, K.N. \& Lincoln, Y. (2011). Qualitative Research. Yogyakarta: Pustaka Pelajar.

Hantoro, J. (2018). Soal Pidato Indonesia Bubar 2030, Prabowo, Ini untuk kita waspadai. Retrieved from http://nasional.tempo.co

Jaffares, S. (2014). Interpreting hashtag politics: policy ideas in an era of Social Media. UK: Palgrave MacMillan.

Lee, J.J. \& Pinker, S. (2010). Rationales for indirect speech: the Theory of Strategic Speaker. Psychological Review, 117(3), 785-807.

Page, R. (2012). the linguistics of self-branding and micro-celebrity in twitter: the role of hashtag. Discourse \& Communication, 6, 181201.

Pinker, S. Nowak, M.A \& Lee, J. . (2008). Proceeding of the National Academy of Sciences. In the Logic of indirect Speech (pp. 2866-2868). USA.

Pinker, S. (2011). Indirech speech, Politeness, Deniability, and Relationships negotiation: Comment on Marina Terkourafis "the Puzzle of Indirech speech". Journal of Pragmatics, 43(11), 857-860.

Rahadian, L. (2018). Mungkinkah \#2019GantiPresiden bikin Indonesia Ganti Presiden. Retrieved from htto://tirto.id/

Weber, I. Garimella, V. R.K \& Teka, A. (2013). Political hashtag trends. In P. et al Serdyukov (Ed.), European Conference on Information Retrieval (pp. 857-860). Berlin: Springer. 